\title{
Campaign Finance Regulation in North America: An Institutional Perspective
}

\author{
Daniel P. Tokaji
}

\begin{abstract}
The regulation of campaign finance is a topic of perennial public concern in North America. The United States has lived through four decades of conflict over contribution and expenditure limits, which has only intensified since the U.S. Supreme Court's decision in Citizens United. Canada has grappled with contribution and expenditure restrictions for decades, though its Supreme Court has taken a more deferential approach. Mexico experienced a spectacularly successful transition to multiparty democracy this century yet faces persistent concerns regarding corruption, agency capture, and powerful party elites. This article compares the campaign finance systems of Canada, Mexico, and the United States, drawing on the institutionalist strain of American election law scholarship. It has four objectives: (1) to provide an overview of the campaign finance laws in each country and the institutions responsible for implementing them; (2) to identify the challenges that each country's campaign finance system faces; (3) to consider what Canada, Mexico, and the U.S. might learn from each other; and (4) to reflect on the broader institutional lessons that might be drawn from their experience. The American model presents the most dysfunctional of the three systems. The Federal Election Commission's bipartisan structure leads to underenforcement of campaign finance rules, while U.S. constitutional law - which rejects equality as a basis for regulation - sharply limits the flow of money into election campaigns. The Mexican and Canadian regulatory models present a sharp contrast, with better functioning institutions that have embraced the goal of promoting a level playing field. Despite the differences, the three North American democracies face some common challenges in ensuring evenhanded implementation. The article concludes with reflections on what these three countries might learn from each other, and the broader institutional lessons for other countries trying to improve their campaign finance institutions.
\end{abstract}

Keywords: campaign finance, Citizens United, comparative law, Mexico, Canada, Federal Election Commission

The first instinct of power is the retention of power

—Former U.S. Supreme Court Justice Antonin Scalia $^{1}$

Daniel P. Tokaji is the Associate Dean for Faculty and the Charles W. Ebersold and Florence Whitcomb Ebersold Professor of Constitutional Law at The Ohio State University, Moritz College of Law, in Columbus, Ohio. He may be contacted at $<$ tokaji.1@osu.edu>. The author thanks Rebecca Barnard and Paul Gatz for their research assistance and Karolina Gilas for comments on an earlier draft. All errors are the author's alone.

\section{INTRODUCTION}

$\mathbf{P}$ UBLIC FAITH IN THE DEMOCRATIC PROCESS is foundering. Existential doubts have often surrounded younger and less stable democracies, but an alarming feature of the present political environment is that even established democracies face grave questions about their capacity to function. The Brexit vote,

\footnotetext{
${ }^{1}$ Mc Connell v. Federal Election Commission, 540 U.S. 93, 263 (U.S. 2003) (Scalia, J., dissenting).
} 
the rise of extremist parties in Europe, and the victory of Donald Trump in the 2016 U.S. presidential election reveal a populist outrage against political elites in countries long viewed as paragons of stability. A common theme of these anti-system movements is that elected leaders have lost touch with the people whom they are supposed to serve, abusing public office to promote their own interests and those of political insiders. The sense that democracy's deck is stacked against ordinary people opens the door to a divisive and potentially explosive populism.

For those concerned about the corruption of democratic politics, the flow of money into politics warrants careful scrutiny. Canada, Mexico, and the United States are among the many democratic countries in which the regulation of campaign finance is a topic of perennial public concern, never more so than now. The United States has lived through four decades of conflict over contribution and expenditure limits, intensifying since the U.S. Supreme Court's decision in Citizens United v. Federal Election Commission ${ }^{2}$ allowed unlimited independent expenditures by corporations and other nonparty groups. Canada has likewise grappled with contribution and expenditure restrictions for decades, most recently through the Fair Elections Act of 2014, though its Supreme Court has taken a more deferential posture toward regulation. Mexico experienced a spectacularly successful transition to multiparty democracy in the last century yet faces persistent concerns regarding clientelism, agency capture, and powerful party elites.

Legal analyses of campaign finance typically focus on the content of the rules regulating how money flows into election campaigns. This is certainly an important subject, but these rules are only part of the campaign finance system. The institutions that implement these rules are equally critical yet often overlooked. A system of campaign finance regulation, after all, is only as strong as the institutions responsible for implementing those rules.

This article examines the campaign finance systems of Canada, Mexico, and the United States, focusing on the administrative agencies that implement campaign finance laws and the judicial institutions that apply and sometimes nullify them. It draws on the institutionalist strain of American election law scholarship, which emphasizes the relationship among legislative, administrative, and judicial institutions. ${ }^{3}$ I have four objectives: (1) to provide an overview of the campaign finance laws in each country and the institutions responsible for implementing them; (2) to identify the challenges that each country's campaign finance system faces; (3) to consider what Canada, Mexico, and the U.S. might learn from each other's experience; and (4) to reflect on the broader institutional lessons that might be drawn from the three North American democracies. ${ }^{4}$

Mexico, Canada, and the U.S. are especially intriguing - albeit challenging - subjects for comparative analysis because of the pronounced differences among their campaign finance systems. The United States vests enforcement of federal campaign finance laws in a bipartisan agency (the Federal Election Commission or FEC) that routinely stalemates along party lines, with a Supreme Court that has frequently intervened to help shape the campaign finance system that exists today. Canada has appointed administrators and enforcers, the chief electoral officer (CEO) of Elections Canada and the commissioner of Canada Elections, with generalist courts empowered to review the constitutionality of parliamentary enactments. Mexico has an Electoral Institute (Instituto Nacional Electoral, or INE) that administers electoral laws, with a specialized Electoral Court (Tribunal Electoral del Poder Judicial de la Federación, or TEPJF) responsible for adjudicating disputes.

The American institutional model presents the most dysfunctional of the three. The FEC's bipartisan structure leads to underenforcement of campaign finance rules, while the constitutional doctrine

\footnotetext{
${ }^{2} 558$ U.S. 310 (U.S. 2010).

${ }^{3}$ Rick Hasen has dubbed this emergent school of thought the "new institutionalism" in election law. Richard L. Hasen, "Election Administration Reform and the New Institutionalism," Cal. L. Rev., 98 (2010), p. 1075. It is related but not identical to the new institutionalism in political science. Daniel P. Tokaji, "The Future of Election Reform: From Rules to Institutions," Yale L. \& Pol'y Rev., 28 (2009), p. 128.

${ }^{4}$ There has been some prior scholarship on campaign finance regulation in North America, including a collection of articles on the three countries published in 2004. See Election L.J., 3 (2004), pp. 395-593. Yet there have been only few comparative analyses of North American campaign finance laws, and none focused on the relation between administrative, legislative, and judicial institutions in all three countries. Robert Boatright has an excellent book on interest groups in Canada and the U.S., analyzing how they have shaped and were shaped by campaign finance rules and public institutions. Robert G. Boatright, Interest Groups and Campaign Finance Reform in the United States and Canada, Univ. of Michigan Press (2011), pp. 12-13. This article has a somewhat different emphasis, focusing on the legal dimension of the relationship among the public institutions responsible for making, implementing, applying, and assessing the constitutionality of campaign finance rules.
} 
developed by the U.S. Supreme Court—which rejects equality as a basis for regulation-sharply limits regulation. The Mexican and Canadian regulatory models present a sharp contrast. Their campaign finance rules are grounded in the ideal of promoting political equality, and their regulatory institutions are much less prone to partisan stalemate. Their courts, moreover, tend to support robust enforcement of campaign finance law rather than restrain it.

Despite the differences, the three North American democracies face a similar matrix of challenges. Their differing approaches illuminate the hazards and tradeoffs inherent in attempting to enforce campaign finance rules evenhandedly. The next part of this article considers the U.S. experience, which has mostly been characterized by regulatory gridlock and judicial deregulation. The third part turns to Canada, a country with a long and strong tradition of independent campaign finance regulation and a more deferential approach to judicial review. The fourth part analyses the experience of Mexico, where independent administrative and judicial institutions have played a central role in facilitating the transition from a one-party state to multiparty democracy. The fifth part concludes with reflections on what these countries might learn from each other, and the broader institutional lessons for other countries trying to improve their systems of campaign finance regulation.

\section{THE UNITED STATES: REGULATORY STALEMATE AND JUDICIAL DEREGULATION}

Although the United States has regulated the flow of money into federal election campaigns for well over a century, ${ }^{5}$ the modern history of campaign finance regulation begins with the Federal Election Campaign Act (FECA) and its 1974 amendments. FECA and subsequent amendments govern elections for U.S. president and the bicameral U.S. Congress consisting of 100 U.S. Senators (elected by state) and 435 U.S. House members (elected from singlemember districts), all chosen through first-past-thepost elections. The 1974 legislation, which was adopted through bipartisan consensus in the wake of the Watergate scandal, created the basic framework of federal campaign finance law that mostly remains in place to this day. ${ }^{6}$ The original structure included expenditure restrictions, contribution restrictions, public financing for presidential elections, and dis- closure requirements, although the expenditure restrictions were held unconstitutional in Buckley $v$. Valeo $^{7}$ and the public financing scheme has become obsolete because its level of funding failed to keep up with the costs of campaigns.

Most pertinent to institutional arrangements, the 1974 FECA amendments created the Federal Election Commission (FEC). The authority of this administrative agency is not as broad as its name might lead one to believe. Its responsibilities are limited to administering and enforcing federal campaign finance laws, not for other matters relating to federal elections. ${ }^{8}$ As originally constituted, the Commission consisted of two members appointed by the president, two appointed by the Speaker of the House of Representatives, and two by the president pro tem of the Senate. In Buckley, the U.S. Supreme Court held that this method of selecting commissioners violates the constitutional principle of separation of powers, leading Congress to reconstitute the Commission. Since 1976, all of the Commission's members have formally been appointed by the president, with an equal number of Republicans and Democrats sitting on the six-person body.

Over the past four decades, both the FEC and the U.S. Supreme Court have played major roles in defining campaign finance law. The FEC mostly exercises its authority through enforcement actions and advisory opinions. Both types of action require a majority vote of the FEC. The tendency of the FEC to deadlock along party lines on important issues has led some advocates to re-brand it the "Failure to Enforce Commission." ${ }^{9}$ Campaign finance reformers have long

\footnotetext{
${ }^{5}$ For an illuminating history of U.S. campaign finance law, see generally Robert E. Mutch, Buying the Vote: A History of Campaign Finance Reform, Oxford Univ. Press (2014).

${ }^{6}$ Richard L. Hasen, "The Nine Lives of Buckley v. Valeo," in Joshua A. Douglas and Eugene D. Mazo (eds.), Election Law Stories, Foundation Press (2016), pp. 292-94.

${ }^{7} 424$ U.S. 1 (U.S. 1976).

${ }^{8}$ For approximately ten years, the Federal Election Commission (FEC) did have authority over one other matter related to federal elections: the uniform federal voter registration form that was mandated by the National Voter Registration Act of 1993 (NVRA). But the Help America Vote Act of 2002 (HAVA) transferred authority over that form to the Election Assistance Commission (EAC), a new federal agency that HAVA created. Thus the FEC's authority now extends only to federal campaign finance laws.

${ }^{9}$ Fred Wertheimer and Don Simon, The FEC: The Failure to Enforce Commission, ACS Issue Brief (2013), <http://www .democracy21.org/wp-content/uploads/2013/02/Wertheimerand-Simon-The-Failure-to-Enforce-Commission-.pdf $>$.
} 
viewed the FEC as a toothless tiger, ${ }^{10}$ and these concerns have intensified in recent years. ${ }^{11}$ Free speech libertarians disagree, with two skeptics calling the agency a "toothless anaconda" that engages in "overenforcement" of the law. ${ }^{12}$ Over the past decade, however, this characterization of the FEC has become less plausible. Deadlocks on the FEC have become much more common, increasing from $2 \%$ of all enforcement votes between 2003 and 2007 to $21 \%$ in 2015 . $^{13}$

Issues surrounding the regulation of "independent expenditures" by nonparty, noncandidate groups have proven especially divisive in the years since Citizens United. The central disputed question is whether particular groups have the "major purpose" of influencing federal elections, which would trigger their designation as political committees and obligate them to report the contributions they receive as well as the expenditures they make in federal elections. The proliferation of groups that appear to be spending money to influence federal elections, yet claim that this is not their major purpose, has led some campaign finance reformers to lament the perceived scourge of "dark money." "The agency frequently splits along party lines, with three Democratic members supporting enforcement and three Republican members opposing it.

Because a majority vote of the FEC is required to pursue enforcement actions, a 3-3 tie means no enforcement. One might imagine the courts stepping into the breach in such cases, effectively breaking FEC ties and ordering enforcement in cases where judges conclude that it is warranted. That is not, however, the role that courts have generally played when the FEC decides not to enforce the law on a deadlocked vote. Instead, the courts generally apply what two Democratic FEC commissioners have labeled "deadlock deference." Where there is a tie vote, the views of the three FEC members who vote against enforcement are effectively treated as controlling and accorded the deference that courts traditionally afford to final agency action. ${ }^{15}$ The upshot is that courts will rarely disturb the FEC's decision not to take enforcement action, even when that decision is the product of a vote that splits evenly along party lines.

In sharp contrast to the passive role that courts have played in enforcement cases, American courtsespecially the U.S. Supreme Court-have long played an active role in reviewing federal and state campaign finance laws. This tradition stretches back four decades to the decision in Buckley. The Court held that the First Amendment to the U.S. Constitution, which prohibits laws abridging the freedom of speech, applies to regulations on political spending and contributions. It struck down FECA's expenditure limits, famously stating: "the concept that government may restrict the speech of some elements of our society in order to enhance the relative voice of others is wholly foreign to the First Amendment ...."16 While rejecting equality as a rationale, it held that restrictions on campaign contributions could be justified by the interest in preventing corruption, upholding FECA's contribution limits on this basis.

The Court's tolerance of campaign finance laws has waxed and waned in the intervening decades, mainly because of changes in the majority's understanding of the anticorruption rationale. For roughly two decades between Buckley and Citizens United, the Court was more deferential to federal and state efforts to regulate campaign finance. Two cases are especially significant. The first was Austin v. Michigan Chamber of Commerce, ${ }^{17}$ which upheld

${ }^{10}$ Donald Simon, "Current Regulation and Future Challenges for Campaign Finance in the United States," Election L.J., 3 (2004), p. 474.

${ }^{11}$ Trevor Potter and Bryson B. Morgan, "The History of Undisclosed Spending in U.S. Elections \& How 2012 Became the "Dark Money" Election," Notre Dame J. L. Ethics \& Pub Pol'y, 27 (2013), p. 383. Ellen L. Weintraub and Samuel C. Brown, "Following the Money: Campaign Finance Disclosure in India and the United States," Election L.J., 11 (2012), p. 241. R. Sam Garrett, Deadlocked Votes Among Members of the Federal Election Commission (FEC): Overview and Potential Considerations for Congress, Congressional Research Service, R40779 (2009).

${ }^{12}$ Bradley A. Smith and Stephen M. Hoersting, "A Toothless Anaconda: Innovation, Impotence, and Overenforcement at the Federal Election Commission," Election L.J., 1 (2002), p. 145.

${ }^{13}$ Public Citizen, Roiled in Partisan Deadlock, Federal Election Commission Is Failing (2016), p. 1, available at <http:// www.citizen.org/documents/fec-deadlock-update-april-2015.pdf $>$. For further background on FEC enforcement deadlocks, see Garrett, supra note 11.

${ }^{14}$ Daniel P. Tokaji and Renata E.B. Strause, The New Soft Money: Outside Spending in Congressional Elections, Election Law@ Moritz, The Ohio State University, Moritz College of Law (2014).

${ }^{15}$ Federal Election Commission v. National Republican Senatorial Committee, 966 F.2d 1471 (D.C. Cir. 1992). For criticism of this deadlock deference, see Ann M. Ravel and Ellen L. Weintraub, "Statement of Vice Chair Ann M. Ravel and Commissioner Ellen L. Weintraub on Judicial Review of Deadlocked Commission Votes" (June 17, 2014), <http://eqs.fec.gov/ eqsdocsMUR/14044354045.pdf>.

${ }^{16}$ Buckley, supra note 7, pp. 48-49.

${ }^{17} 494$ U.S. 652 (U.S. 1990). 
a state prohibition on corporations spending money from their treasuries to influence candidate campaigns. Justice Thurgood Marshall's opinion for the majority in Austin distinguished Buckley on the ground that corporations were different from individuals, deeming the "corrosive and distorting effects of immense aggregations of wealth" accumulated through the corporate form an adequate rationale for restricting their campaign spending. ${ }^{18}$ By implication, this meant that the federal ban on corporate expenditures - which had been in place even before FECA - was also constitutional.

The second important post-Buckley case was McConnell v. FEC, ${ }^{19}$ which upheld most of the Bipartisan Campaign Reform Act of 2002 (BCRA), the most important federal campaign finance legislation since 1974 . BCRA was mainly designed to close two loopholes in federal law that had emerged in the decades since Buckley. The first was "soft money," unrestricted contributions given to political parties as a way of getting around contribution restrictions. The other was so-called "sham" issue ads, broadcast advertisements that purported to address policy issues but were really designed to influence federal elections. BCRA closed the soft money loophole while prohibiting corporate and union funding for "electioneering communications," defined to include identifying a candidate for federal office within 30 days of a primary election or 60 days of a general election. Despite the use of the word "Bipartisan" in its title, BCRA was mostly supported by Democrats in Congress, though a number of prominent Republicans-none more so than Senator and future presidential candidate John McCain-were steadfast supporters of the legislation as well. The McConnell majority opinion, coauthored by Justices John Paul Stevens and Sandra Day O'Connor, was especially noteworthy for its expansive anticorruption rationale, which led it to uphold BCRA's soft money and electioneering provisions. ${ }^{20}$

The Court's relatively deferential posture toward campaign finance rules ended with the Roberts Court, whose skepticism of campaign finance regulation has been manifest in its narrower conception of the anticorruption rationale. The shift in the Court's approach resulted from a change in personnel: the replacement of Chief Justice William Rehnquist with Chief Justice Roberts and, more importantly, the replacement of Associate Justice O'Connor with Associate Justice Samuel Alito. While Justice O'Connor furnished the fifth vote for upholding most of BCRA, Justice Alito has consistently voted to strike down restrictions on campaign contributions and expenditures. The most prominent example is Citizens United, which overruled Austin and part of McConnell, holding that the federal ban on corporate expenditures for campaign ads violates the First Amendment. ${ }^{21}$ This holding rests on a contraction of the corruption rationale, which has been like an accordion in the Court's hands over the years-narrow in Buckley, wider in Austin and McConnell, and narrow again in Citizens United and other decisions of the Roberts Court. One might fairly ask whether it is the U.S. Supreme Court as an institution or the ideology of the specific individuals who occupy it that accounts for the severe restraints on campaign finance regulationand the accompanying flood of money-that are hallmarks of the U.S. system. While this question is inherently difficult to answer, both the institution and the individuals on it are surely responsible. The tightening constraints on contribution and expenditure limits that the Roberts Court has imposed are due to its personnel changes. But skepticism of most forms of regulation, especially spending limits, has been an enduring feature of U.S. constitutional law for over four decades.

Whatever its root causes, the Supreme Court's aggressive intervention has led to a federal campaign finance system that is as much the product of its handiwork as statutes passed by Congress or regulations adopted by the FEC. Under Buckley and Citizens United, there are no limits on independent expenditures by individuals, corporations, labor unions, or other groups. ${ }^{22}$ Most of the contribution limits that Congress enacted through FECA and BCRA remain in place. That includes limits on individual contributions to candidates, currently set at $\$ 2,700$ per election. There used to be limits on aggregate contributions - the total amount that individuals could contribute to all federal candidates,

\footnotetext{
${ }^{18} I d$., p. 660.

${ }^{19}$ Supra note 1.

${ }^{20}$ Id.

${ }^{21}$ Citizens United, supra note 2.

${ }^{22} \mathrm{An}$ important exception is foreign nationals (including foreign citizens, corporations, and other groups) which are prohibited from making expenditures and contributions in U.S. elections. 52 U.S.C. $\S$ 30121. See also Bluman v. Federal Election Commission, 800 F. Supp. 2d 281 (D.D.C. 2011), aff'd, 565 U.S. 1104 (2012) (upholding ban on foreign contributions and expenditures).
} 
parties, and other political committees-but those were eliminated by the Court's decision in $\mathrm{McC}$ utcheon v. Federal Election Commission. ${ }^{23}$ BCRA's limits on soft money contributions to political parties remain in place, at least for now, due to a part of the McConnell decision that remains good law. However, there is no limit on contributions to groups that only make independent expenditures, commonly known as "super PACs," due to a lower court decision following Citizens United.

To review, federal campaign finance law in the U.S. (1) limits contributions to candidates and political parties, (2) does not limit contributions to outside groups that make independent expenditures, (3) does not limit expenditures by individuals, corporations, labor unions, or other groups. The upshot is a system that no reasonable person would design and that is widely viewed as dysfunctional. Two years ago, Renata Strause and I published a study called The New Soft Money, based primarily on interviews with people across the ideological spectrum. ${ }^{24}$ Those included former congressional candidates, campaign staff, and people affiliated with outside groups. Most surprising to us was the degree of agreement, both on how the current system functions and the fact that it functions poorly. In particular, respondents of widely divergent political views lamented the fact that more of the money spent to influence congressional campaigns comes from outside groups and less of it through the political parties. This leads to diminished accountability and worries about increasing political polarization.

While there is general agreement on the dysfunctionality of the U.S. campaign finance system, the two major parties point the finger of blame in opposite directions. Republicans generally blame Congress for restricting campaign contributions, while Democrats blame Citizens United and other judicial decisions. Yet their diagnosis of the malady is remarkably similar, even if their explanation of its precipitating cause differs. In particular, there is growing evidence that the growth of outside spending in election campaigns - relative to spending by the political parties-has unfortunate implications for governance, contributing to the marked increase in political polarization in recent years. ${ }^{25}$ Making matters worse is the fact that an increasing portion of the sources of this outside money is undisclosed, coming from so-called "dark money" groups that claim not to have the major purpose of influencing elections as noted above.
It may seem paradoxical that an increase in party polarization would accompany a decrease in the power of party leaders, but the two developments are related. Strong partisan attachments are nothing new in American politics. Almost from the beginning, the U.S. has had a two-party system, a consequence of its combination of districted, first-past-the-post legislative elections and national presidential elections. ${ }^{26}$ These two attributes of the American system combine to make it extremely difficult for third parties to gain a foothold. In fact, the U.S. has had not only a strong two-party system but the same two parties since before the Civil War. Nor are acrimonious battles between the two parties a new phenomenon in the U.S. The first contested presidential election in 1800, between the incumbent Federalist president John Adams and his friend and rival, DemocraticRepublican challenger Thomas Jefferson, was a bitter one even by contemporary lights.

While the American two-party system is hardly new, what $i s$ new is the dramatic increase in partisan polarization. An increasing gulf separates Republicans and Democrats on issues as seemingly unrelated as taxes, abortion, gun control, marriage equality, health care, and other social welfare programs. Both politicians and voters line up in predictable ways across these issues, to an extent not seen in other countries. ${ }^{27}$ At the same time, the center of American politics has shrunk almost to the point of disappearance. A half-century or even a quarter-century past, there were many Democrats to the right of some Republicans in Congress, and many Republicans to the left of some Democrats. That is no longer the case: the most conservative Democrat is more liberal than the most liberal

\footnotetext{
${ }^{23} 134$ S. Ct. 1434 (U.S. 2014).

${ }^{24}$ Tokaji and Strause, supra note 14.

${ }^{25}$ Bruce Cain, Democracy More or Less: America's Political Reform Quandary, Cambridge Univ. Press (2015). Richard H. Pildes, "Romanticizing Democracy, Political Fragmentation, and the Decline of American Government," Yale L.J., 124 (2014), p. 804. Nathaniel Persily, "Stronger Parties as a Solution to Polarization," in Nathaniel Persily (ed.), Solutions to Political Polarization in America, Cambridge Univ. Press (2015).

${ }^{26}$ E.E. Schattschneider, Party Government, Holt, Rinehart and Winston (1942). Maurice Duverger, Political Parties: Their Organization and Activity in the Modern State, Wiley, 2d Eng. ed. (1959).

${ }^{27}$ Richard Gunther and Kuan Hsin-chi, "Value Cleavages and Partisan Conflict," in Richard Gunther, José Ramón Montero, and Hans-Jürgen Puhle (eds.), Democracy, Intermediation, and Voting on Four Continents, Oxford Univ. Press (2007).
} 
Republican, and vice versa. The same holds true of voters. Few Democrats are more conservative than even the most liberal Republican.

A robust and expanding body of academic literature examines the reasons for the increase in polarization. ${ }^{28}$ There are many potential contributing causes, including increasing geographical segregation of Democrats in urban areas and Republicans in rural areas; the increasingly partisan character of the American news media, both old and new; and the ideological sorting that followed the civil rights legislation of the mid-1960s. These are probably all playing a role, but there is an emerging consensus that the altered channels through which money flows into politics are an important part of the story. ${ }^{29}$ Party leaders in the U.S., already weak in comparison to other countries, are further disadvantaged by the rapid increase in nonparty independent expenditures compared to those of political parties. This makes it difficult for party leaders like Senate Majority Leader Mitch McConnell and House Speaker Paul Ryan to rein in extreme factions within their own party. To reiterate, the party leaders' lack of control over financial resources makes it difficult for them to induce cooperation. This phenomenon is particularly problematic in a presidential system with a bicameral legislature like that of the U.S., in which lawmaking depends on bipartisan cooperation. Even the most basic functions of government, like keeping the lights of the federal government on and preventing it from defaulting on its debt, have led to protracted and nerve-wracking uncertainty. The way money flows through into election campaigns is surely not the only cause of the partisan polarization and accompanying paralysis of Congress, but it is just as surely a part of the explanation.

The point is to emphasize the connection between the institutions responsible for implementing campaign finance laws and broader questions of governance. One part of the institutional problem has to do with the agency responsible for enforcing campaign finance laws. Divided along party lines, the FEC has been unable to check the rapid growth in outside spending, much of it coming from groups that deny that they are "political committees" and therefore don't disclose their donors. An even more serious problem arises from the unconstructive relationship between Congress, the FEC, and the U.S. Supreme Court. Federal campaign law is now an amalgam of statutes enacted by Congress, rules made and administered by the FEC, and decisions from the Supreme Court. Under current Supreme Court precedent, some contribution limits, public financing, and disclosure requirements are permissible, but restrictions on expenditures (at least ones made independent of a candidate) are not. The result is a campaign finance system in which the monies flowing through candidates and parties are limited, but the monies flowing through unaccountable and polarizing outside groups aren't. No one would design such a system if starting from scratch. It is instead the unhealthy relationship among the institutions collectively responsible for making federal campaign finance law-Congress, the FEC, and the Courtthat has created this Frankenstein monster of a system.

As noted above, a primary objective of this article is to consider what the U.S. might learn from the experience of its neighbors to the north and the south, in particular whether they offer models that the U.S. might emulate. Another goal is to consider whether the U.S. experience holds cautionary lessons for Canada and Mexico, as they seek to avoid a similar descent into dysfunction. With these ideas in mind, I turn to the Canadian and Mexican campaign finance systems, in that order.

\section{CANADA: INDEPENDENT ADMINISTRATION AND JUDICIAL DEFERENCE}

Of the three North American countries, Canada has the longest tradition of politically independent electoral institutions. ${ }^{30}$ It also has the longest history of regulating the flow of money in politics, with disclosure requirements first imposed in 1874 and a comprehensive campaign finance scheme

\footnotetext{
${ }^{28}$ For a sampling, see Alan I. Abramowitz, The Disappearing Center, Yale Univ. Press (2010); Sean Theriault, Party Polarization in Congress, Cambridge Univ. Press (2008). Michael J. Barber and Nolan McCarty, "Causes and Consequences of Polarization," in Nathaniel Persily (ed.), Solutions to Political Polarization in America (2015); and Richard H. Pildes, "Why the Center Does Not Hold: The Causes of Hyperpolarized Democracy in America," Cal. L. Rev., 99 (2011), pp. 273-333. ${ }^{29}$ Cain, supra note 25; Persily, supra note 25; Pildes, supra note 25.

${ }^{30}$ Jean-Pierre Kingsley, "The Administration of Canada's Independent, Non-Partisan Approach," Election L.J., 3 (2004), p. 406.
} 
adopted exactly a century later. ${ }^{31}$ The U.S. and Canada thus adopted foundational campaign finance statutes at the same time. While the two countries have faced similar questions in the intervening years, they have chosen to answer them in radically different ways. From an American perspective, examination of Canada's campaign finance system is like viewing an alternative universe, affording an opportunity to imagine what might have been had U.S. governing institutions made different choices over the past four decades.

There are two main sources of the divergence between Canada and the U.S. The first is that Canada has independent administrative and enforcement authorities, not the bipartisan structure that has stymied effective regulation in the U.S. Not coincidentally, the Canadian public generally has a high level of confidence in Elections Canada, the agency that administers campaign finance and other federal election laws. ${ }^{32}$ The second is the much more deferential approach to judicial review adopted by Canada's Supreme Court. A decade ago, there appeared to be some convergence between the American and Canadian Supreme Courts' approaches to campaign finance, with both courts loosening the reins. ${ }^{33}$ That has all but disappeared with the Roberts Court's aggressive judicial review of federal campaign finance laws over the past decade, detailed in the previous part. Over roughly the same period, Canada has witnessed greater partisanship over campaign finance legislation, in contrast to the consensus model that prevailed before $2003 .^{34}$ This raises the question of whether Canada's Supreme Court has become too deferential, inadequately policing laws that may be designed to benefit the party in power at the expense of its opponents. ${ }^{35}$

Some background on Canada's electoral system will inform analysis and comparison. Canada has a parliamentary system but, like the U.S., elects its representatives in its lower house on a firstpast-the-post basis through electoral districts (called "ridings"). ${ }^{36}$ Although multiple parties hold seats in the House of Commons, the Liberal and Conservative parties have mostly been the two strongest, followed by the New Democrats and the separatist Bloc Québécois. Canada's parliamentary structure results in more party-centered elections than in the United States, where presidential candidates tend to be the focal point. ${ }^{37}$

While both countries have a strong federalist tradition, the administration and enforcement of cam- paign finance laws is much more centralized in Canada than in the U.S. Moreover, Canada has long vested responsibility for administering and enforcing its election laws in nonpartisan entities, in contrast to the bipartisan (and frequently stalemated) model of the FEC. The Canada Elections Act provides administrative, injunctive, and criminal means to ensure compliance, with three distinct offices vested with responsibility over it: (1) the chief electoral officer (CEO) of Elections Canada, (2) the commissioner of Canada Elections (the commissioner), and (3) the director of public prosecutions (the director). ${ }^{38}$

Elections Canada is the federal agency responsible for administering elections, including campaign finance laws. ${ }^{39}$ The CEO position was originally created in 1920 by the Dominions Elections Act, which was amended in 1927 to vest appointing power in the House of Commons rather than the government, where it lies to this day. ${ }^{40}$ The CEO was formerly allowed to hold office until a mandatory retirement age of 65, but under the Fair Election Act (FEA) of 2014, he or she is limited to a single, nonrenewable ten-year term. ${ }^{41}$ The CEO's

\footnotetext{
${ }^{31}$ Donald J. Bourgeois and Susan B. Campbell, Election Law in Canada, Butterworths (Canada) (2015). Lisa Young, "Regulating Campaign Finance in Canada: Strengths and Weaknesses," Election L.J., 3 (2004), p. 444. Janet L. Hiebert, "Elections, Democracy and Free Speech: More at Stake than an Unfettered Right to Advertise," in K.D. Ewing and Samuel Issacharoff (eds.), Party Funding and Campaign Financing in International Perspective, Hart Publishing (2006), pp. 269-89.

${ }^{32}$ Paul G. Thomas and Lorne R. Gibson, Comparative Assessment of Central Electoral Agencies: A Report Commissioned by Elections Canada (2014), p. 31.

${ }^{33}$ Christopher P. Manfredi and Mark Rush, Judging Democracy, Univ. of Toronto Press (2008).

${ }^{34}$ Lisa Young, "Shaping the Battlefield: Partisan Self-Interest and Election Finance Reform in Canada, 2003-2014," in Robert G. Boatright (ed.), The Deregulatory Moment?: A Comparative Perspective on Changing Campaign Finance Laws, Univ. of Michigan Press (2015), pp. 107-25.

${ }^{35}$ Yasmin Dawood, "The Supreme Court of Canada and the Electoral Process," J. Parl. \& Pol. L., 8 (2014), p. 378.

${ }^{36}$ Boatright, supra note 4, pp. 13, 36.

${ }^{37} I d$., pp. 36-37.

${ }^{38}$ Diane R. Davidson, "Enforcing Campaign Finance Laws: What Others Can Learn from Canada," Election L.J., 3 (2004), p. 537. Bourgeois and Campbell, supra note 31 , pp. 158-201.

${ }^{39}$ Thomas and Gibson, supra note 32, p. 27.

${ }^{40}$ Bourgeois and Campbell, supra note 31 , p. 158 . Thomas and Gibson, supra note 32, p. 27.

${ }^{41}$ CEA (Canada Elections Act), Pt. $2, \S 13(1)$. Bourgeois and Campbell, supra note 31, p. 158. Thomas and Gibson, supra note 32 , p. 28.
} 
statutory powers include supervising the conduct of elections, ensuring that all election officers comply with the Canada Elections Act (CEA) issuing instructions of its administration, and otherwise administering the law. ${ }^{42}$ Also by statute, an Advisory Committee of Political Parties consisting of two representatives of each registered party provides nonbinding advice and recommendations to the CEO. $^{43}$

While the CEO of Elections Canada is mainly responsible for administration, federal law vests primary responsibility over enforcement in a different official: the commissioner of Canada Elections. ${ }^{44}$ This position was created in 1974, and the commissioner was given general enforcement responsibility in $1977 .{ }^{45}$ The statute states the powers of the commissioner broadly but vaguely, saying that he or she may "take any measures ... in relation to an inquiry, injunction or compliance agreement under the Act." ${ }^{46}$ The commissioner is expressly empowered to seek injunctive relief to enforce the CEA as well as compliance agreements. ${ }^{47}$

Until recently, the commissioner was selected by the CEO of Elections Canada, but the Fair Elections Act of 2014 (FEA) transferred that authority to the director of public prosecutions, who is barred from even consulting the CEO on whom to appoint. ${ }^{48}$ The 2014 law also placed the commissioner within the Office of the Director for Public Prosecutions, although the commissioner is supposed to conduct investigations "independent" of the director. ${ }^{49}$ While the commissioner investigates possible violations, the director of public prosecutions has authority to determine whether criminal proceedings should be instituted. The commissioner and director have since agreed to a protocol, designed to keep the investigatory and prosecutorial functions separate. ${ }^{50}$

Of all the differences between the United States' and Canada's campaign finance systems, none is more stark or consequential than the role that their national supreme courts have played. Both countries' campaign finance systems derive from a statute enacted in $1974 .{ }^{51}$ Both countries have a generalist supreme court. And both countries face difficult questions regarding judicial review, concerning the extent to which courts should serve as a check on partisan manipulation of electoral rules. ${ }^{52}$ But from there, the two courts paths have diverged sharply. While not a rubber stamp, the Canadian Supreme Court takes a much more deferential approach than the U.S. Supreme Court.

To understand these differences, it is helpful to trace the development of campaign finance law in Canada during the same period summarized above with respect to the U.S. The same year the U.S. Congress adopted the FECA Amendments challenged in Buckley (1974), Canada's Parliament adopted the Election Expenses Act. The original statute limited candidate and party spending while prohibiting other entities from making independent expenditures to support or oppose candidates. ${ }^{53} \mathrm{It}$ also required disclosure of contributions and provided public financing in the form of tax credits for contributions. ${ }^{54} \mathrm{~A}$ loophole in the independent expenditure ban allowed groups to spend money if made in "good faith" to indicate support for a candidate's policy views, prompting Parliament to adopt a second statute in 1983 to ban all independent expenditures. ${ }^{55}$ The flat ban on independent expenditures was not enforced, however, after a lower court declared it unconstitutional. ${ }^{56}$

The Royal Commission on Electoral Reform and Party Financing (the Lortie Commission) released a comprehensive report on Canada's election laws in 1991, recommending substantial changes. ${ }^{57}$ The Lortie Commission specifically highlighted the need to limit independent expenditures, to provide

${ }^{42}$ CEA, Pt. 2, $\S 16$; Thomas and Gibson, supra note 32, pp. $28-$ 29. Bourgeois and Campbell, supra note 31, pp. 158-61.

${ }^{43}$ CEA, Pt. 2, $\S 21.1$.

${ }^{44}$ CEA, Pt. 19, § 509. Bourgeois and Campbell, supra note 31, p. 171.

${ }^{45}$ Davidson, supra note 38 , p. 538.

${ }^{46}$ CEA, Pt. $19, \S 513$. Bourgeois and Campbell, supra note 31 , p. 178.

${ }^{47}$ CEA, Pt. 19, $\S \S 516,517$. Bourgeois and Campbell, supra note 31 , pp. 178-79.

${ }^{48}$ CEA, Pt. 19, $\S 509(1)$. Bourgeois and Campbell, supra note 31, p. 171.

${ }^{49}$ CEA, Pt. 19, $\S \S 509.1(1)$ and 510(3).

${ }^{50}$ Bourgeois and Campbell, supra note 31, pp. 173-77.

${ }^{51}$ Hiebert, supra note 31 , p. 272; Bourgeois and Campbell, supra note 31, pp. 9-10.

${ }^{52}$ Dawood, supra note 35. Yasmin Dawood, "Electoral Fairness and the Law of Democracy: A Structural Rights Approach to Judicial Review," University of Toronto L.J., 62 (2012), pp. 499-561.

${ }^{53}$ Hiebert, supra note 31, p. 272.

${ }^{54}$ Bourgeois and Campbell, supra note 31 , p. 10; Boatright, supra note 4, p. 73.

${ }^{55}$ Hiebert, supra note 31 , p. $272-73$

${ }^{56}$ National Citizens' Coalition v. Canada (Attorney General), 5 WWR 436 (Alta QB 1984). Hiebert, supra note 31, p. 273.

${ }^{57}$ Bourgeois and Campbell, supra note 31, pp. 3-6, 109-11. 
candidates with access to the broadcast media, and to improve disclosure of the sponsor of election ads. ${ }^{58}$ In making these recommendations, the commission emphasized the central value of being able to participate equally in the process of democratic governance. $^{59}$

Parliament responded in 1993 with a third statute, adopting a $\$ 1,000$ expenditure limit on partisan independent expenditures and improved disclosure. ${ }^{60}$ The Alberta Court of Appeals upheld this limit, but the Canadian Supreme Court disagreed in Libman v. Quebec. ${ }^{61}$ Although Libman actually involved a different issue, the constitutionality of independent expenditures in Quebec referendum campaigns, the Court's statement sent Parliament back to the drawing board. Parliament enacted its fourth attempt to regulate independent expenditures in $2000 .^{62}$ The Canada Elections Act of 2000 prohibited nonparty groups from spending more than $\$ 150,000$ in the aggregate, and $\$ 3,000$ per riding. ${ }^{63}$

The Supreme Court of Canada upheld the restrictions imposed by the 2000 statute in Harper v. Canada. ${ }^{64}$ The Harper decision is remarkable for its self-conscious rejection of the approach that the U.S. Supreme Court has mostly followed since Buckley. The Canadian Supreme Court embraced equality as a justification for restricting the flow of outside money into election campaigns just as decisively as the U.S. Supreme Court rejected it in Buckley and Citizens United. But the Harper majority opinion goes further in upholding Parliament's egalitarian objectives with respect to the independent expenditure restrictions, saying that "the state can restrict the voices which dominate the political discourse so that others may be heard as well." 65 While past Canadian decisions (including Libman and Figueroa v. Canada ${ }^{66}$ ) had looked skeptically at rules governing party finance, the Harper decision adopted a deferential approach. ${ }^{67}$

Around the time of Harper, some election law scholars argued that there had been a "convergence" in the American and Canadian courts, given their relatively deferential posture toward restrictions adopted by the national legislature. ${ }^{68}$ That was plausible given the then-recent Supreme Court decision in McConnell, but U.S. constitutional law has shifted enormously since then. Citizens United is just one example of the U.S. divergence from the more deferential approach that these cases employ. The U.S. Supreme Court has also overturned individual campaign contribution limits, ${ }^{69}$ aggre- gate contribution limits, ${ }^{70}$ and even a state public financing scheme. ${ }^{71}$

By contrast, Canadian courts have generally followed the more deferential approach that Harper suggests. Some scholars argue that the Canadian Court is too deferential, allowing the dominant party to adopt rules that entrench itself at the expense of rival parties. ${ }^{72}$ Before 2003, campaign finance rules were mostly the product of consensus among the major parties. ${ }^{73}$ Since then, governing parties have attempted and in some instances accomplished changes to campaign finance laws without cross-partisan consensus. In 2003, while Harper was pending, when the Liberal Party held control of government, it adopted legislation that lowered the contribution limit and banned most contributions from entities other than individuals. ${ }^{74}$ Prime Minister Chrétien pushed this legislation through, despite the opposition of right-of-center parties. ${ }^{75}$ After the Conservative Party regained power, it adopted campaign finance changes that strengthened its own hand. Early in the administration of Conservative Prime Minister Stephen Harper, Parliament enacted the Accountability Act of 2006. As previously noted, this law removed prosecutorial authority from the Commissioner, requiring him or her to instead refer prosecutions to the director of public prosecutions. $^{76}$ It also lowered the individual

\footnotetext{
${ }^{58} I d$., p. 109.

${ }^{59}$ Royal Commission on Electoral Reform and Party Financing, Reforming Electoral Democracy, Minister of Supply and Services Canada (1991), p. 322.

${ }^{60}$ Hiebert, supra note 31, p. 273.

${ }^{61} 3$ SCR 569 (Can. 1997).

${ }^{62}$ Hiebert, supra note 31, p. 273.

${ }^{63}$ Boatright, supra note 4 , p. 75.

${ }^{64} 1$ SCR 827 (Can. 2004).

${ }^{65}$ Id., p. 62.

${ }^{66} 1$ SCR 912 (Can. 2003).

${ }^{67}$ For further background, see Daniel P. Tokaji, "The Obliteration of Equality in American Campaign Finance Law: A TransBorder Comparison," J. Parl. \& Pol. L., 5 (2011), p. 396.

${ }^{68}$ Manfredi and Rush, supra note 33. p. 115. Yasmin Dawood, Book Review, "Judging the Law of Democracy," Election L.J., 8 (2009), p. 143.

${ }^{69}$ Randall v. Sorrell, 548 U.S. 230 (U.S. 2006).

${ }^{70}$ McCutcheon, supra note 22.

${ }^{71}$ Arizona Free Enterprise Club's Freedom Club PAC v. Bennett, 564 U.S. 721 (U.S. 2011).

${ }^{72}$ Manfredi and Rush, supra note 33, p. 108.

${ }^{73}$ Young, supra note 34 , pp. 110-11.

${ }^{74}$ Id., p. 112; Boatright, supra note 4, p. 75.

${ }^{75}$ Young, supra note 34, p. 113.

${ }^{76}$ Thomas and Gibson, supra note 32 , at 29.
} 
contribution limit and completely banned corporate and union contributions. ${ }^{77}$ Several commentators argued that these restrictions advantaged the Conservative Party while doing little to address flaws in the existing campaign finance regime. ${ }^{78}$ In 2011 , the Conservatives enacted legislation reducing party funding by eliminating the per-vote subsidy. ${ }^{79}$ Although this legislation had a negative effect on all parties' revenue, its relative impact on the Conservatives was not as severe as that on its rivals. ${ }^{80}$

Similar concerns of partisan self-dealing attended the most recent changes to campaign finance law, the FEA of 2014, enacted by the Conservative Parliament at the end of Prime Minister Harper's tenure. In addition to changing the method of appointing the commissioner of Canada Elections, the FEA amended substance of campaign finance law, aiming to create a "closed system" in which all permissible contributions and expenditures are accounted for and no monies enter from outside. ${ }^{81}$ The government also proposed a relaxation of the spending limit, one that would disproportionately have benefitted the Conservative Party, but ultimately withdrew this provision. ${ }^{82}$ The legislation did change a variety of other electoral rules, some of which were likely to help the Conservative Party by making it more difficult for some people to vote.

These developments recall Justice Scalia's warning about the "first instinct of power." They suggest that Canada has stepped away from its tradition of cross-partisan consensus, moving instead toward a system in which the dominant party adopts rules that are designed to entrench itself in power. To the extent that Harper is understood as adopting a hands-off posture, it may embolden self-entrenching campaign finance reforms. In this regard, it is noteworthy that the post-Harper amendments to Canadian campaign finance law have not been constitutionally challenged. ${ }^{83}$

There are, however, some good reasons for the Canadian Supreme Court's more deferential posture, which reflect underlying differences between the American and Canadian models of judicial review. One is the fact that, unlike the U.S. Constitution, Canada's Charter of Rights and Freedoms expressly provides that rights-including freedom of expression and association-are subject to "such reasonable limits prescribed by law as can be demonstrably justified in a free and democratic society." 84 This textual difference can only explain so much, however, given that U.S. constitutional law com- monly considers other values that may justify restrictions on constitutional rights. In the context of campaign finance, for example, contribution limits may be justified if closely drawn to the important interest in preventing corruption or its appearance. ${ }^{85}$

More important, the idea of a "dialogue" between the courts on one side and political actors (legislatures and agencies) on the other is a defining characteristic of Canadian constitutional law. ${ }^{86}$ The concept of dialogue gives lawmaking bodies some ability to modify or even reverse decisions made by courts. ${ }^{87}$ This is formally true in Canada, which empowers Parliament to declare that one of its enactments should be given effect for a limited time, "notwithstanding" a judicial declaration of its constitutional invalidity. ${ }^{88}$ Although the "notwithstanding clause" is rarely invoked, ${ }^{89}$ its very existence suggests an approach to constitutional review that stands in marked contrast to the American idea of judicial supremacy, a hallmark of U.S. constitutional law since Marbury v. Madison. True to form, the U.S. Supreme Court has exhibited very little interest in encouraging a dialogue with either Congress or the FEC in the realm of campaign finance law. If anything, it has been

\footnotetext{
${ }^{77}$ Young, supra note 34, p. 115; Dawood, supra note 35, p. 378; Bourgeois and Campbell, supra note 31, p. 11.

${ }^{78}$ Colin Feasby, "Constitutional, Questions about Canada's New Political Finance Regime," Osgoode Hall L.J., 45 (2007), pp. 528-29. Heather MacIvor, "A Missed Opportunity: Political Finance and the Federal Accountability Act," J. Parl. \& Pol. L. 1 (2008), pp. 105, 107. Christopher Stoney and Catherine Waters, "The Federal Accountability Act: The Impact of Changes in Party Finances on the Democratic Functions of Political Parties," J. Parl. \& Pol. L., 1 (2008), p. 157.

${ }^{79}$ Young, supra note 34, p. 117.

${ }^{80} I d$., p. 118.

${ }^{81}$ Bourgeois and Campbell, supra note 31, p. 90.

${ }^{82}$ Young, supra note 34, pp. 120-21.

${ }^{83}$ Id., p. 121.

${ }^{84}$ Canadian Charter of Rights \& Freedoms, $\S 1$.

${ }^{85}$ Nixon v. Shrink Missouri Government PAC, 528 U.S. 377, 387-88 (2000) (quoting Buckley, 424 U.S. 1 (1976), p. 30).

${ }^{86}$ Peter Hogg and Allison Bushell, "The Charter Dialogue Between Courts and Legislatures (Or Perhaps the Charter of Rights Isn't Such a Bad Thing After All," Osgood Hall L.J., 35 (1997), p. 79.

${ }^{87}$ Dawood, supra note 68, p. 142.

${ }^{88}$ Colin Feasby, "The Supreme Court of Canada's Political Theory and the Constitutionality of the Political Finance Regime," in K.D. Ewing and Samuel Issacharoff (eds.), Party Funding and Campaign Financing in International Perspective, Hart Publishing (2006), p. 245.

${ }^{89}$ Id.
} 
unusually proactive in holding statutes constitutional, most notably in Citizens United, in which the plaintiff did not raise the constitutional issue until invited to do so by the Court, and in which the majority opinion declined to adopt a narrowing construction of the statute that would have obviated the need to address the constitutional question. ${ }^{90}$

Whatever its shortcomings, Canada's campaign finance system compares favorably to that of the United States. Its independent administrative and enforcement entities have generally functioned effectively, while its courts have played a much less disruptive role than the U.S. Supreme Court. In particular, Canada's Supreme Court has avoided the U.S. Supreme Court's mistake of arrogating to itself the authority to declare the core democratic value of equality off-limits. Nor has the Canadian Supreme Court been a complete pushover. It has sometimes struck down laws that go too far by imperiling the ability of outsiders to compete with insiders, most notably the restriction on minor parties struck down in Figueroa. The more balanced approach of Canada's Supreme Court results from the institutional features described in the preceding paragraph, as well as from the individuals who sit on it. Finally, there is a high degree of consensus in Canada on the need to limit expenditures by candidates and political parties and to provide public funding for election expenses. ${ }^{91}$

Still, campaign finance reformers, in the U.S. and elsewhere, should be wary of idealizing the Canadian experience. Canada's system faces some present or looming challenges, which may be divided into three categories.

\section{Enforcement authority}

One of the key questions surrounding Canada's system of campaign finance regulation is whether its existing institutions are up to the task of monitoring, investigating, and prosecuting violations of the law. There are looming questions about whether Canada's administrative and enforcement authorities (the CEO of Elections Canada and commissioner of Canada Elections) have sufficient investigatory, compliance, and enforcement tools at their disposal, particularly in an era where more spending is likely to go underground. Given the partial breakdown in Canada's tradition of multi-partisan consensus on campaign finance regulation, it is possible to imagine a future parliament chipping away at their tools of compliance and enforcement. Such changes could turn Canada's administrative and enforcement agencies into toothless tigers.

\section{Conflicts of interest}

One of the most worrisome changes to Canada's campaign finance system is the transfer of authority for appointing the commissioner, from the CEO of Elections Canada to the director of public prosecutions, and the placement of the commissioner's office within the authority of the director. This creates the potential for politically motivated enforcement decisions or, perhaps more likely, nonenforcement decisions. The protocol to which the director and commissioner have agreed should help, but there are storm clouds on the horizon. One could imagine future attempts to erode the autonomy of Elections Canada or the commissioner, which have made them models of independent enforcement around the world.

\section{Entrenchment}

Perhaps the most serious concern surrounding Canada's campaign finance systems is the threat of future legislation designed to entrench the party in power, at the expense of its rivals. There are strong reasons to believe that some aspects of recent changes to campaign finance laws were motivated by the "first instinct of power," specifically the incumbent party's interest in maintaining control of the government by making it more difficult for rival parties to compete. ${ }^{92}$ The deferential posture adopted by the Canadian Supreme Court-at least relative to the U.S.- raises concerns that selfentrenching campaign finance laws will be allowed to remain in place. As Yasmin Dawood cogently argues, judicial review of such changes presents formidable challenges for constitutional courts,

\footnotetext{
${ }^{90} \mathrm{~A}$ venerable canon of American statutory interpretation holds that courts should generally avoid declaring a law unconstitutional if an alternative statutory ground is available. The canon of constitutional avoidance has the effect of putting the ball back in the legislature's court, thus bearing a resemblance to the Canadian ideal of dialogue. Yet the Supreme Court has not applied the so-called avoidance canon in campaign finance cases, most notably Citizens United, supra note 2. See Richard L. Hasen, "Constitutional Avoidance and Anti-Avoidance by the Roberts Court," Sup. Ct. Rev. (2009), p. 181.

${ }^{91}$ Young, supra note 34, pp. 107-25.

${ }^{92} I d$., pp. 110-21.
} 
especially ones that embrace equality as a permissible government interest. ${ }^{93}$ It is difficult if not impossible to measure the effect of wealth upon elections. ${ }^{94}$ This makes it challenging to judge whether a particular limitation on contributions and expenditures will actually advance the equality interest that Harper embraced. But more searching judicial review of campaign finance laws raises its own set of problems. ${ }^{95}$ Not only is it sometimes difficult to assess the degree to which a particular law will advantage the incumbent party, but it is tempting for judges to substitute their own value judgments for the decisions that the legislature has made. There is, accordingly, no easy answer to the question of how much deference constitutional courts should give to campaign finance rules adopted by the legislature. Canada's experience over the past several years, however, suggests it would be appropriate for the Court to engage in a more searching review of partisan self-dealing than it did in the Harper decision.

\section{MEXICO: INSTITUTIONALIZING MULTIPARTY DEMOCRACY}

Mexico is the youngest of the three North American democracies. Its transition from an autocratic one-party state to a robust multiparty democracy is a textbook example of the transformational power of independent electoral institutions, specifically its election management body and electoral court. While first created as a fig leaf for the ruling party, these institutions became more independent over time and eventually facilitated the transition to a multiparty democracy. While there can be no denying its enormous progress, Mexico's system faces serious challenges, including an infusion of illegal money into politics, worries about party bosses, and attendant risks of corruption. Mexico's experience thus reveals the necessity of regularly updating campaign finance rules and institutions to meet emerging threats.

Some basic structural differences between Mexico and its two neighbors to the north must be acknowledged at the outset. Aside from the relative youth of Mexico's democracy and its language and cultural differences, the most fundamental is that its legal system is grounded in the civil law tradition rather than the English common law tradition. Like the U.S. (and unlike Canada), Mexico has a presidential system, although a new president is elected every six years and is strictly limited to a single term. Perhaps the most important structural difference is the method of conducting legislative elections, which relies on a combination of districted and proportional-representation seats. In both chambers of Mexico's bicameral national legislature, members are elected through a combination of districts and proportional representation. The upper chamber of Congress (the Senate) has 128 seats while the lower chamber (the Chamber of Deputies) has 500. Three-quarters of Senators are elected by state, with the winning party receiving two seats and the second-place party receiving one seat in each state. The remaining one-quarter of senatorial seats are allocated proportionally among political parties. Deputies are also elected through a mixed system as well, with 300 elected from districts on a first-past-the-post basis and the remaining 200 allocated proportionally among parties. $^{96}$

Mexico's elections-including its system of campaign finance-are administered by an independent agency, formerly IFE (Instituto Federal Electoral or Federal Electoral Institute) and now INE (Instituto Nacional Electoral or National Electoral Institute). Mexico vests responsibility for the adjudication of electoral disputes in an Electoral Court, which now goes by the acronym TEPJF (Tribunal Electoral del Poder Judicial de la Federacíon or Electoral Tribunal of the Federal Judicial Branch). The TEPJF decides tens of thousands of cases each year, on a diverse range of electoral matters. ${ }^{97}$ Over the decades, there have been several waves of reform to Mexico's campaign finance rules and electoral institutions. A review of the creation and maturation of these institutions is essential to understanding how it managed such a successful transition to multiparty democracy, the challenges it currently faces, and what other countries might learn from Mexico's experience.

\footnotetext{
${ }^{93}$ Dawood, supra note 35 , pp. $379-84$.

${ }^{94} I d$., p 380; Colin Feasby, "Issue Advocacy and Third Parties in the United States and Canada," McGill L.J., 48 (2003), pp. 18-19.

${ }^{95}$ Dawood, supra note 35 , p. 381.

${ }^{96}$ Gilles Serra, "The 2012 Elections in Mexico: Return of the Dominant Party," Electoral Studies, 34 (2014), p. 349.

${ }^{97}$ Tribunal Electoral del Poder Judicial de la Federacíón or Electoral Tribunal, Statistics, <http://www.trife.gob.mx/en/ turnos-sentencias/statistics>.
} 
From the 1920s until the 1980s, Mexico was a oneparty state dominated by the PRI (Partido Revolucionario Institucional or Institutional Revolutionary Party). The PRI maintained its hold on national power for decades through a combination of fierce party discipline and deal-making with opposition parties, sometimes referred to as contracesiónes or gentleman's agreements. ${ }^{98}$ The demolition of PRI's firewall did not take place with a single stroke, but rather through its piece-by-piece disintegration over time. The system that exists today is best understood as a product of a lengthy process of give-and-take among Mexico's three major parties. ${ }^{99}$

The creation and strengthening of the independent electoral institutions, administrative and judicial, are critical elements in the story. Before the establishment of the Electoral Institute and Electoral Court, Mexico's elections were run by a supervisory commission pursuant to a law adopted in 1946 and amended in $1951 .^{100}$ Progress occurred in the 1980s when meaningful public funding of political parties was established for the first time and a somewhat more independent election authority was created to administer these funds. ${ }^{101}$ PRI nevertheless retained power by positioning itself between the two main opposition parties, the right-leaning PAN (Partido Acción Nacional or National Action Party) and the left-leaning PRD (Partido de la Revolución Democrática or Democratic Revolution Party). ${ }^{102}$

The first specialized electoral tribunal, dubbed "Tricoel," was established in 1987. In its original form, this court consisted of seven magistrates, nominated by the political parties and approved by Congress, which retained the ultimate power to resolve electoral disputes. ${ }^{103}$ Further reforms followed the 1988 election, which was marred by allegations of fraud surrounding the victory of PRI candidate Carlos Salinas. ${ }^{104}$ In response, Congress adopted the Federal Code of Electoral Institutions (COFIPE). Among its reforms was to create an autonomous Electoral Institute run by a General Council, consisting of six members appointed by a two-thirds vote of the lower chamber of Congress. ${ }^{105}$ In conjunction with an increase in proportional representation seats and greater transparency in election administration, the more autonomous Electoral Institute weakened PRI's hold on power. ${ }^{106}$ In addition, a new electoral court (Tribunal Federal Electoral [TRIFE] or Federal Electoral Tribunal) was established. The new court enjoyed greater authority than its predecessor, although the new tribunal's rulings could still be reviewed and modified by a two-thirds vote of the Electoral College. ${ }^{107}$

In the 1990s, the Zapatista guerilla movement in Chiapas created an atmosphere of instability that prompted another wave of administrative and judicial reform. ${ }^{108}$ A 1993 law increased the regulation of campaign finance and required political parties to submit campaign finance reports to IFE annually and after each federal election. ${ }^{109}$ The following year, the process for selecting the IFE's General Council was modified under reforms agreed to by all the major political parties. Under the new system, six citizen councilors were made a majority of the eleven-member board. ${ }^{110}$ The parties in

${ }^{98}$ Jacqueline Peschard, "Federal and Local Electoral Institutions: From a National to a Fragmented System," in Andrew Selee and Jacqueline Peschard (eds.), Mexico's Democratic Challenges: Politics, Government, and Society, Woodrow Wilson Press (2010), p. 71. Todd A. Eisenstadt, "The Origins and Rationality of the 'Legal Versus Legitimate' Dichotomy Invoked in Mexico's 2006 Post-Electoral Conflict," PS Polit. Sci. Polit., 40 (2007), p. 39. Todd A. Eisenstadt, "Catching the State Off Guard: Electoral Courts, Campaign Finance, and Mexico's Separation of State and Ruling Party," Party Pol., 10 (2004), p. 727.

${ }^{99}$ Jean-François Prud'homme, "The Restructuring of the Party System in the Wake of the 2006 Elections," in Andrew Selee and Jacqueline Peschard (eds.), Mexico's Democratic Challenges: Politics, Government, and Society, Woodrow Wilson Center Press (2010), p. 51.

${ }^{100}$ Jacqueline Peschard, "Mexico's Search for Credibility," Election L.J., 3 (2004), p. 412.

${ }^{101}$ Jacqueline Peschard, "Control over Party and Campaign Finance in Mexico," Mex. Stud., 22 (2006), p. 83. Fransje Molenaar and Rocio Martínez, Mexico Elections 2012: A Study of the Regulation and Oversight of Political Parties' Financial Resources, IFES (2012), p. 4.

${ }^{102}$ Eisenstadt, 2004, supra note 98, p. 728. Peschard, supra note 98 , p. 72.

${ }^{103}$ Eisenstadt, 2004, supra note 98, p. 729.

${ }^{104} I d$., p. 728. Antonio Ugues, Jr. and D. Xavier Medina Vidal, "Public Evaluations of Electoral Institutions in Mexico: An Analysis of the IFE and TRIFE in the 2006 and 2012 Elections," Electoral Studies, 40 (2015), p. 232.

${ }^{105}$ Peschard, supra note 100, at 413; Ugues and Vidal, supra note 104 , p. 232.

${ }^{106}$ Eisenstadt, 2004, supra note 98, p. 728.

${ }^{107}$ Eisenstadt, 2004, supra note 98, pp. 730-31. Ugues and Vidal, supra note 104, p. 232. Dylan McNally, "Mexico's National Electoral Institute: Ensuring Fair Elections at the Local Level,” Baker Institute (2014), p. 1, <http://www.baker institute.org/files/7851/>.

${ }^{108}$ Eisenstadt, 2004, supra note 98, pp. 728-29. McNally, supra note 107, p. 1. Peschard, supra note 98, p. 73.

${ }^{109}$ Molenaar, supra note 101, p. 4.

${ }^{110} \mathrm{McNally}$, supra note 107 , p. 1 . Eisenstadt, 2004, supra note 98, p. 728. 
Congress nominated these citizen councilors who were then approved by a two-thirds vote of the chamber, effectively removing the president from the process. ${ }^{111}$ In addition, the Electoral Court's authority over case management and the collection of evidence was enhanced, although some reforms adopted in 1994 gave the president more power over the court, arguably diminishing its independence. ${ }^{112}$

For the first time in its history, Mexico adopted constitutional electoral reforms in 1996 with the consensus of all the political parties represented in Congress. ${ }^{113}$ A major component of this reform was to constitutionalize the requirement that election campaigns primarily be funded from public rather than private sources. ${ }^{114}$ Equally central was the strengthening of the institutions responsible for overseeing Mexican elections. The Electoral Institute was given constitutional status, while its independence from the executive branch was increased. ${ }^{115}$ The reforms also created a new entity (Comisión de Fiscalización or Finance Commission) within the IFE to monitor campaign finances. ${ }^{116}$ Also in 1996, the Electoral Court assumed its current form as a part of the judicial branch of government, with the final power to resolve elections. ${ }^{117}$ Under these reforms, judges of the court are nominated by the Mexican Supreme Court and ratified by a two-thirds vote in the Senate. ${ }^{118}$ The Electoral Court's jurisdiction was extended in 1996 to encompass state and local elections. ${ }^{119}$ This made the court a key actor in the resolution of electoral disputes. ${ }^{120}$

Mexico's institutional reforms ultimately helped bring down PRI's firewall. The signal moment was the election of PAN candidate Vincente Fox in 2000, ending over seven decades of PRI dominance at the national level. ${ }^{121}$ This did not happen overnight, but was instead the consequence of progressive institutional changes of the preceding decades, including the creation and strengthening of the Electoral Institute and Electoral Tribunal. ${ }^{122}$ Though originally created to legitimate PRI's authority, these institutions nurtured the development of multiparty democracy. ${ }^{123}$ By 2000 , the Electoral Institute had earned a high level of credibility with the Mexican people, with 74 percent expressing confidence in the agency, a level of support comparable to that of the military and the Catholic Church. ${ }^{124}$ Mexico's election management body and court have also earned praise from election scholars and observers around the world. ${ }^{125}$
Mexico's subsequent history reveals the necessity of continually reviewing electoral rules and institutions. There have been some highly publicized incidents of noncompliance with campaign finance laws, including the "Pemexgate" scandal involving a state-owned oil company and its trade union which supported PRI, and the "Amigos de Fox" scandal involving civic groups supporting victorious PAN candidate Fox in $2000 .{ }^{126}$ Both cases resulted in substantial fines. ${ }^{127}$

The contested 2006 presidential election produced an unprecedented challenge to the credibility of Mexico's electoral institutions, yet both emerged with their credibility intact. The election was breathtakingly close with PAN candidate Felix Calderón winning 36.7 percent of the vote and PRD candidate Andrés Manual López Obrador at 36.1 percent, with PRI candidate Roberto Madrazo Pintado a distant third at 22.7 percent. Although narrowly behind after the initial count, López Obrador proclaimed himself the winner and alleged that fraud had denied him victory. The Electoral Court ultimately upheld PAN candidate Calderón's victory over López Obrador. ${ }^{128}$ It found some irregularities but concluded

${ }^{111}$ Peschard, supra note 101, p. 85; Federico Estévez, Eric Magar and Guillermo Rosas, "Partisanship in Non-Partisan Electoral Agencies and Democratic Compliance: Evidence from Mexico's Federal Electoral Institute," Electoral Studies, 27 (2008), p. 260.

${ }^{112}$ Eisenstadt, 2004, supra note 98, p. 731-32.

${ }^{113}$ Peschard, supra note 101, p. 87.

${ }^{114}$ Molenaar, supra note 101, p. 4.

${ }^{115} \mathrm{McNally}$, supra note 107, p. 1; Peschard, supra note 101, p. 103.

${ }^{116}$ Estévez, et al., supra note 111, p. 258.

${ }^{117}$ Ugues and Vidal, supra note 104, p. 232.

${ }^{118}$ Eisenstadt, 2004, supra note 98, pp. 731-32.

${ }^{119}$ Id., pp. 731-32. Ugues and Vidal, supra note 104, p. 232.

${ }^{120}$ Prud'homme, supra note 99, p. 52.

${ }^{121}$ Eisenstadt, 2007, supra note 98, p. 41.

${ }^{122}$ Estévez, et al., supra note 111, p. 258.

${ }^{123}$ Eisenstadt, 2004, supra note 98.

${ }^{124} \mathrm{McNally}$, supra note 107 , p. 2.

${ }^{125}$ Ugues and Vidal, supra note 104, p. 232. Eisenstadt, 2007, supra note 98, pp. 41-42.

${ }^{126}$ Peschard, supra note 101, at 98; Shannon K. O’Neil, “Campaign Financing in Mexico," Council on Foreign Relations (blog) (July 10, 2013), <http://blogs.cfr.org/oneil/2013/07/10/ campaign-financing-in-mexico/>.

${ }^{127} J o s e ́$ De Jesús Orozco Henríquez, "Financing and Monitoring Political Parties in Mexico: Strengths and Weaknesses," Election L.J., 3 (2004), p. 471. Peschard, supra note 101, pp. 100, 102.

${ }^{128}$ Gilles Serra, "The Risk of Partyarchy and Democratic Backsliding: Mexico's 2007 Electoral Reform," Taiwan J. of Democracy, 8 (2012), pp. 39-40. Eisenstadt, 2007, supra note 98 , p. 42. 
that they were not so grave as to undermine the result. ${ }^{129}$ Despite criticisms surrounding their perceived lack of transparency, ${ }^{130}$ the general consensus is that the Electoral Institute and the Electoral Court performed admirably. ${ }^{131}$ Public confidence in these institutions initially declined, but they later regained the trust of most Mexicans. ${ }^{132}$

Another round of electoral reforms followed the 2006 election, and the three major parties ultimately agreed to constitutional amendments in 2007 and statutory reforms in 2008. ${ }^{133}$ The reforms included a new formula for party funding, restrictions on political contributions from private sources, and additional disclosure requirements. ${ }^{134}$ By providing substantial free airtime to parties while prohibiting private individuals and groups running ads, the reforms strengthened the hand of party leaders. ${ }^{135}$ They also included restrictions on the content of campaign speech, prohibiting messages that slander or denigrate a political opponent. ${ }^{136}$ In addition, an autonomous unit within IFE, Unidad de Fiscalización de los Recursos de los Partidos Politicos (UFRPP, or Political Party Resources Oversight Unit), was established to monitor and investigate campaign finance violations. ${ }^{137}$ Some commentators worry that these reforms have compromised the political neutrality of the Electoral Institute while strengthening the hand of party bosses and restricting freedom of speech. ${ }^{138}$

The 2012 election saw the once-dominant PRI regain the presidency after a dozen years in the wilderness. PRI candidate Enrique Peña Nieto won the election with 31.2 percent of the vote, defeating PRD candidate López Obrador (26.3\%) and PAN's Josefina Eugenia Vázquez Mota. ${ }^{139}$ There were allegations of foul play by PRI supporters during the campaign including a scheme to funnel money into party coffers and the "Sorianagate" scandal, involving the alleged use of prepaid phone cards to buy votes. ${ }^{140}$ While PAN's Vázquez Mota conceded on election night, PRD candidate López Obrador again cried fraud and contested the election. Again, the Electoral Court wound up affirming the result, prompting López Obrador to accuse the court of being "staffed by white collar criminals." This time, however, López Obrador's own party distanced itself from his inflammatory allegations, leading him to break from PRD. ${ }^{141}$ This indicates an increase in the credibility that Mexico's electoral institutions enjoy, even in the face of electoral irregularities. $^{142}$
Mexico subsequently underwent another round of electoral reforms, the most significant of which was to vest its national election management body with responsibility over state and local elections as well as federal elections. With that change, the Federal Electoral Institute (IFE) became the National Electoral Institute (INE). The rationale for this reform was that the state electoral authorities formerly responsible for handling subnational elections were more vulnerable to manipulation and mismanagement. PRI still controlled these state-level institutes, causing PAN and PRD to successfully press for more centralized control, which was accomplished in 2014. ${ }^{143}$ Three specific changes increased INE's power over subnational elections. First, the Electoral Institute has greater control over the process through which the state electoral institutes' councilors are selected. It can even assume their responsibilities at the request of four Electoral Institute councilors or the majority of a subnational council. Second, the Electoral Institute has increased oversight over political parties operating at the subnational level by virtue of a new audit commission, consisting of five members of INE's General Council. Third, magistrates of the states' electoral tribunals are now elected by a two-thirds vote of the federal Senate, effectively minimizing local politicians' power over the judiciaries

\footnotetext{
${ }^{129}$ Serra, supra note 128 , pp. $39-40$; McNally, supra note 107 , p. 3.

${ }^{130}$ John M. Ackerman, "The 2006 Elections: Democratization and Social Protest," in Andrew Selee and Jacqueline Peschard (eds.), Mexico's Democratic Challenges: Politics, Government, and Society, Woodrow Wilson Center Press (2010), pp. 99-103.

${ }^{131}$ Eisenstadt, 2007, supra note 98, p. 42.

${ }^{132}$ Roderic Ai Camp, "Expanding Participation: The Electoral Process," in Politics in Mexico: Democratic Consolidation or Decline, 6th ed. (2014), pp. 239-40, 256; McNally, supra note 107, p. 2.

${ }^{133}$ Serra, supra note 128 , p. 40 . Prud'homme, supra note 99 , p. 54.

${ }^{134}$ Molenaar, supra note 101, p. 5; O'Neil, supra note 126

${ }^{135}$ Serra, supra note 96, p. 350; Heather K. Gerken, "Mexico's 2007 Election Reforms: A Comparative View," Mexican L. Rev., 2 (2009), pp. 166-67.

${ }^{136}$ Ai Camp, supra note 132, p. 240. Serra, supra note 128 , pp. 48-49. Serra, supra note 96, p. 350.

${ }^{137}$ Molenaar, supra note 101, pp. 5, 18.

${ }^{138}$ Serra, supra note 128 , pp. $43,45,49$.

${ }^{139}$ Serra, supra note 96 , pp. 350-51.

${ }^{140}$ Ugues and Vidal, supra note 104, p. 233. Serra, supra note 96, p. 352; O’Neil, supra note 126.

${ }^{141}$ Serra, supra note 96 , p. 352.

${ }^{142}$ Ugues and Vidal, supra note 104, p. 241.

${ }^{143}$ McNally, supra note 107, p. 2.
} 
in their states. ${ }^{144}$ In theory, these reforms should result in greater consistency, integrity, and impartiality in the administration of election laws, including those governing campaign finance. ${ }^{145}$

Mexico's administrative and judicial institutions have undoubtedly played a critical role in the country's successful transition from a one-party state to multiparty democracy. Yet Mexico faces formidable challenges when it comes to the administration and enforcement of campaign finance laws. A new group of judges now occupies the Electoral Court, replacing those who completed their ten-year terms in 2016. As this article goes to press, the country has just completed another tumultuous presidential election. In his third run for the presidency, López Obrador won by a large margin, garnering over 53\% percent of the vote as the candidate of the National Regeneration Movement (Movimiento Regeneración Nacional or MORENA). While López Obrador adopted a milder tone than in his prior campaigns, controversies over the enforcement of campaign finance laws persist. After the election, the Electoral Institute issued a whopping $\$ 10$ million fine against MORENA over a trust the party had created for earthquake victims, a decision López Obrador labelled "an act of vengeance." 146

Although it is too soon to draw any definitive conclusions from Mexico's 2018 election, three general concerns warrant particular attention.

\section{Evasion}

Foremost among Mexico's challenges is contributions and expenditures outside the system, a phenomenon comparable to the growth of "dark money" in U.S. elections. The Amigos for Fox, PEMEX, and Soriana scandals are examples of a persistent and, in the view of some commentators, growing black money problem. ${ }^{147}$ Some commentators estimate that illegal contributions are more than four times the legal limit. ${ }^{148}$ There are multiple explanations for this phenomenon. One is the longstanding and difficult-to-overcome culture of clientelism in Mexican politics. ${ }^{149}$ Wealthy actors seeking to curry influence will, on this argument, find ways around restrictions on contributions and expenditures. A related explanation for the black market in political money is that these limits are too low, creating a strong incentive for moneyhungry candidates to find additional sources of support. ${ }^{150} \mathrm{An}$ alternative argument is that the problem arises not so much from the rules themselves as from inadequate enforcement. ${ }^{151}$ On this view, there is a need to strengthen the authority of the INE, giving it enhanced tools to monitor and investigate under-the-table funding of political campaigns. ${ }^{152}$ There is good reason to believe that the Electoral Institute lacks the capacity to effectively monitor and detect violations of campaign finance rules. $^{153}$

\section{Big Brother}

While some argue that the Electoral Institute has insufficient authority, others argue that Mexico's administrative and electoral institutions have grown too powerful. Some of these concerns arise from the 2006 election, during which some complained about both IFE's and TEPJF's lack of transparency in handling the complaints of PRD candidate López Obrador. ${ }^{154}$ From this perspective, the post-2006 reforms may have exacerbated the problem, particularly the prohibition on messages that denigrate or slander political opponents. ${ }^{155}$ To those schooled in the United States' free speech tradition, such a prohibition raises a red flag, especially given that the law does not define these terms. Such vaguely defined restrictions on political expression have the effect of vesting considerable discretion in those charged with enforcing the law,

\footnotetext{
${ }^{144} I d$., pp. 2-3.

${ }^{145}$ Ugues and Vidal, supra note 104, p. 243.

${ }^{146}$ Reuters Staff, "Incoming Mexico Leader Blasts Campaign Fine as 'Act of Vengeance,"' Reuters (July 20, 2018), $<$ https://www.reuters.com/article/us-mexico-election-lopezo brador/incoming-mexico-leader-blasts-campaign-fine-as-act-ofvengeance-idUSKBN1KB017>

${ }^{147}$ Alejandro Poiré, "Tackling Corruption in Mexico Means Reforming Campaign Finance," Financial Times (Dec. 12, 2014), <https://www.ft.com/content/2161a2f9-a59b-3aef-b0bd46ba92011fe5>.

${ }^{148}$ O'Neil, supra note 126; Luis Carlos Ugalde and Mario Guzmán, "En las Urnas: Más Dinero, Más Corrupción," Nexos (Aug. 1, 2013), <https://www.nexos.com.mx/?p=15453>.

${ }^{149}$ Poiré, supra note 147; O'Neil, supra note 126.

${ }^{150}$ Poiré, supra note 147.

${ }^{151}$ Centro de Estudios Espinosa Yglesias, "Fortelezas y Debilidades del Sistema Electoral Mexicano (2000-2012)" (2013).

${ }^{152}$ O'Neil, supra note 126.

${ }^{153}$ Karolina Mónika Gilas and Mikaela Jenny Christiansson, "El Nuevo Modelo de Fiscalización: La Reforma Fallida," Revista Mexicana de Estudios Electorales, 16 (2016), pp. 92125.

${ }^{154}$ Ackerman, supra note 130 .

${ }^{155}$ Serra, supra note 128 , p. 48; Ai Camp, supra note 132 , p. 240.
} 
allowing them to suppress viewpoints that they find objectionable. Moreover, such broadly worded restrictions on political speech could deprive citizens of information that could affect their voting choices. ${ }^{156}$ There is strong consensus within Mexico on the necessity of an autonomous electoral management body. ${ }^{157}$ The country's history demonstrates that the growing authority of its electoral institutions was essential in achieving robust interparty competition. Yet centralization of power in INE could ultimately become a liability, an instrument of authoritarianism rather than a check on it. ${ }^{158}$

\section{Partyarchy}

The third major concern is that Mexico's rules and institutions give too much control to party leaders, making it practically impossible for outsiders to challenge them. This concern arises from both how campaign finance roles restrict the flow of money and from the structure of its electoral institutions. Mexican law channels public funding through the political parties while sharply limiting private contributions and expenditures, as detailed above. This empowers party bosses at the expense of those who would seek to challenge their power, potentially leading to democratic backsliding in the form of "partyarchy," as Gilles Serra has called it - the concentration of power in the hands of a few party leaders. ${ }^{159}$ In addition, some commentators worry that the parties have too much control over the Electoral Institute, particularly the selection of its general councilors. This is a version of agency capture, the central concern being that the regulator is effectively dominated by the regulated entities, in this case political parties. ${ }^{160}$

Like the "Big Brother" concern, this one has roots in the 2006 election, especially PRD supporters' concerns that they were shut out of the process by which councilors were chosen. ${ }^{161}$ Empirical studies of Mexican elections partially validate this concern, showing some evidence of partisan behavior on the part of the Electoral Institute, with councilors often protecting the interests of the party that was responsible for selecting. ${ }^{162}$ Another empirical study finds that confidence in Mexico's election authorities is higher among citizens whose preferred candidates won in both 2006 and 2012, and especially low among supporters of PRD candidate López Obrador, who came in second in both presidential elections. ${ }^{163}$ Yet there is a countervailing ar- gument that it's healthy for the parties to have some degree of influence over regulators, insofar as it inspires faith in the system among various factions within the electorate. ${ }^{164}$ In this regard, it is important to remember that Mexico's successful transition to democracy was forged through compromises among the major parties. It is also helpful to contrast Mexico's experience with that of the United States. A growing body of scholarship argues that party leaders' lack of authority is responsible for the political polarization that contributes to legislative gridlock. ${ }^{165}$ On this line of thinking, the power that Mexico's system vests in party leaders is actually a good thing, forestalling the paralysis that has made Mexico's neighbor to the north practically ungovernable.

\section{CONCLUSION}

Closely examining the campaign finance system of any single country, let alone three, can leave one overwhelmed by the enormity of the task. Difficult choices among multiple competing values-among them liberty, competition, equality, and integrityare unavoidable. Even where there is a general consensus on the governing rules, it is difficult ensure that they are administered and enforced fairly, without bias towards incumbents or the dominant party. To paraphrase Justice Scalia, administrative and judicial institutions are always at risk of succumbing to the first instinct of power.

At the same time, a transborder comparison of campaign finance systems may also offer rays of hope to those seeking to strengthen democracy by regulating the flow of money into electoral campaigns. The experience of Mexico's Electoral Institute and Electoral Court are testament to the transformative power of credible electoral institutions. So too, independent administrative and judicial

\footnotetext{
${ }^{156}$ Serra, supra note 128 , p. 49.

${ }^{157}$ Peschard, supra note 98 , p. 81.

${ }^{158} \mathrm{McNally}$, supra note 107.

${ }^{159}$ Serra, supra note 128 , pp. 51-54. Gerken, supra note 135 , pp. 166-67.

${ }^{160}$ Gerken, supra note 135 , pp. $170-71$.

${ }^{161}$ Ackerman, supra note 130.

${ }^{162}$ Estévez, et al., supra note 111, p. 269.

${ }^{163}$ Ugues and Vidal, supra note 104. Ai Camp, supra note 132, p. 256.

${ }^{164}$ Estévez, et al., supra note 111, p. 259.

${ }^{165}$ Pildes, supra note 25 . Cain, supra note 25 . Persily, supra note 25 .
} 
institutions can safeguard public faith in established democracies, as the decades-long experience of Elections Canada and the commissioner of Canada Elections demonstrates. These institutions have long track records of implementing campaign finance laws fairly and effectively, if not always perfectly.

Electoral institutions in the U.S. compare unfavorably to those of its neighbors to the north and south. The Federal Election Commission, so bitterly divided along party lines that it can barely function at all, is a textbook example of what to avoid. The U.S. Supreme Court has even more severely undermined campaign finance law through its obliteration of equality as a permissible rationale for regulation and concomitant invalidation of all limits on independent expenditures. This toxic combination of regulatory stalemate and aggressive judicial intervention has led to the breakdown of the American campaign finance system, exacerbating political polarization and stratification. Although political turmoil is rarely attributable to any single cause, it is not difficult to connect the dots between the United States' dysfunctional campaign finance system and the existential difficulties that American democracy now confronts.

The lessons that the U.S. might draw from the experience of its neighbors are thus painfully clear. Improvements to its campaign finance system depend not only on a better set of rules but also on stronger administrative entities that-like those in Canada and Mexico - enjoy some degree of insulation from partisan politics. The U.S. Supreme Court would also benefit from observing the examples of Canada's Supreme Court and Mexico's Electoral Court. Both of these institutions have embraced the egalitarian aspirations embodied in their countries' campaign finance laws, avoiding the effective rewriting of campaign finance laws that has characterized the U.S. Supreme Court's interventions for most of the past four decades. Strong judicial institutions are essential to ensure the laws are effectively and fairly enforced, but they can also play a disruptive and destabilizing role, as the U.S. experience from Buckley through Citizens United reveals.

Less clear is what other countries can learn from the U.S. experience, aside from the obvious if unspecific lesson of avoiding its example. The most alarming possibility is that the breakdown of the American campaign finance system could be a harbinger of things to come in Canada, Mexico, and other democratic countries. Comparison of three countries' experience makes abundantly clear that maintenance of an effective campaign finance system demands eternal vigilance. As instrumental as Mexico's electoral institutions have been to its transition to multiparty democracy, their continued success will depend on the delicate task of preserving insulation from partisan politics without losing the buy-in of the major political parties. Though some observers of Mexico's system may worry about "partyarchy," the U.S. experience reveals the dangers that arise when party leaders' control over campaign resources is diminished. The challenge is to ensure that party leaders have adequate control over financial resources, while preventing the dominant party from undermining its rivals. Canada's recent experience suggests that even well-established administrative institutions may be vulnerable when the dominant party seeks to compromise their independence. This may in turn call for judicial institutions like the Supreme Court of Canada to play a more assertive role than they traditionally have. Though the U.S. Supreme Court's overly aggressive approach should be avoided, there are risks in being too deferential as well.

If there is anything that the combined experience of the United States, Canada, and Mexico can teach the world, it is that cabining that first instinct of power is a never-ending task. Establishing and maintaining credible campaign finance institutions is necessary though not sufficient to achieve that end.

\section{REFERENCES}

Abramowitz, Alan I. The Disappearing Center: Engaged Citizens, Polarization, and American Democracy, Yale University Press (2010).

Ackerman, John M. "The 2006 Elections: Democratization and Social Protest," in Andrew Selee and Jacqueline Peschard (eds.), Mexico's Democratic Challenges: Politics, Government, and Society, Woodrow Wilson Center Press (2010).

Arizona Free Enterprise Club's Freedom Club PAC v. Bennett, 564 U.S. 721 (U.S. 2011).

Austin v. Michigan Chamber of Commerce, 494 U.S. 652 (U.S. 1990).

Barber, Michael J. and Nolan McCarty, "Causes and Consequences of Polarization," in Nathaniel Persily (ed.), Solutions to Political Polarization in America (2015).

Bluman v. Federal Election Commission, 800 F. Supp. 2d 281 (D.D.C. 2011).

Boatright, Robert G. Interest Groups and Campaign Finance Reform in the United States and Canada, University of Michigan Press (2011). 
Bourgeois, Donald J. and Susan B. Campbell, Election Law in Canada, Butterworths (Canada) (2015).

Buckley v. Valeo, 424 U.S. 1 (U.S. 1976).

Cain, Bruce. Democracy More or Less: America's Political Reform Quandary, Cambridge University Press (2015).

Camp, Roderic Ai. "Expanding Participation: The Electoral Process," in Politics in Mexico: Democratic Consolidation or Decline, 6th ed. (2014).

Centro de Estudios Espinosa Yglesias, "Fortelezas y Debilidades del Sistema Electoral Mexicano (2000-2012)" (2013).

Citizens United v. Federal Election Commission, 558 U.S. 310 (U.S. 2010).

Davidson, Diane R. "Enforcing Campaign Finance Laws: What Others Can Learn from Canada," Election Law Journal, 3 (2004), p. 537.

Dawood, Yasmin. "Electoral Fairness and the Law of Democracy: A Structural Rights Approach to Judicial Review," University of Toronto L.J., 62 (2012), p. 499.

Dawood, Yasmin. Book Review, "Judging the Law of Democracy," Election Law Journal, 8 (2009), p. 141.

Dawood, Yasmin. "The Supreme Court of Canada and the Electoral Process," Journal of Parliamentary \& Political Law, 8 (2014) p. 373.

Duverger, Maurice. Political Parties: Their Organization and Activity in the Modern State, Wiley, 2d English ed. (1959).

Eisenstadt, Todd A. "Catching the State Off Guard: Electoral Courts, Campaign Finance, and Mexico's Separation of State and Ruling Party," Party Politics, 10 (2004), p. 723.

Eisenstadt, Todd A. "The Origins and Rationality of the 'Legal Versus Legitimate’ Dichotomy Invoked in Mexico's 2006 Post-Electoral Conflict," PS Political Science Politics, 40 (2007), p. 39.

Estévez, Federico, Eric Magar, and Guillermo Rosas. "Partisanship in Non-Partisan Electoral Agencies and Democratic Compliance: Evidence from Mexico's Federal Electoral Institute," Electoral Studies, 27 (2008), p. 257.

Federal Election Commission v. National Republican Senatorial Committee, 966 F.2d 1471 (D.C. Cir. 1992).

Feasby, Colin. "Constitutional, Questions about Canada's New Political Finance Regime," Osgoode Hall Law Journal, 45 (2007), pp. 528-29.

Feasby, Colin. "Issue Advocacy and Third Parties in the United States and Canada," McGill Law Journal, 48 (2003).

Feasby, Colin. "The Supreme Court of Canada's Political Theory and the Constitutionality of the Political Finance Regime," in K.D. Ewing and Samuel Issacharoff (eds.), Party Funding and Campaign Financing in International Perspective, Hart Publishing (2006).

Figueroa v. Canada, 1 SCR 912 (Can. 2003).

Garrett, R. Sam. Deadlocked Votes Among Members of the Federal Election Commission (FEC): Overview and Potential Considerations for Congress, Congressional Research Service, R40779 (2009).

Gerken, Heather K. "Mexico's 2007 Election Reforms: A Comparative View," Mexican Law Review, 2 (2009), p. 163.

Gilas, Karolina Mónika and Mikaela Jenny Christiansson. "El Nuevo Modelo de Fiscalización: La Reforma Fallida," Revista Mexicana de Estudios Electorales, 16 (2016), p. 92.
Gunther, Richard and Kuan Hsin-chi, "Value Cleavages and Partisan Conflict," in Richard Gunther, José Ramón Montero, and Hans-Jürgen Puhle (eds.), Democracy, Intermediation, and Voting on Four Continents, Oxford University Press (2007).

Harper v. Canada, 1 SCR 827 (Can. 2004).

Hasen, Richard L. "Constitutional Avoidance and AntiAvoidance by the Roberts Court," Supreme Court Review (2009), p. 181.

Hasen, Richard L. "Election Administration Reform and the New Institutionalism," California Law Review, 98 (2010). p. 1075.

Hasen, Richard L. "The Nine Lives of Buckley v. Valeo," in Joshua A. Douglas and Eugene D. Mazo (eds.), Election Law Stories, Foundation Press (2016).

Hiebert, Janet L. "Elections, Democracy and Free Speech: More at Stake than an Unfettered Right to Advertise," in K.D. Ewing and Samuel Issacharoff (eds.), Party Funding and Campaign Financing in International Perspective, Hart Publishing (2006).

Hogg, Peter and Allison Bushell, "The Charter Dialogue Between Courts and Legislatures (Or Perhaps the Charter of Rights Isn't Such a Bad Thing After All)," Osgoode Hall Law Journal, 35 (1997), p. 75.

Kingsley, Jean-Pierre. "The Administration of Canada's Independent, Non-Partisan Approach," Election Law Journal, 3 (2004), p. 406.

Libman v. Quebec, 3 SCR 569 (Can. 1997).

MacIvor, Heather. "A Missed Opportunity: Political Finance and the Federal Accountability Act," Journal of Parliamentary \& Political Law. 1 (2008), pp. 105.

Manfredi, Christopher P. and Mark Rush, Judging Democracy, University of Toronto Press (2008).

McConnell v. Federal Election Commission, 540 U.S. 93, 263 (U.S. 2003).

McCutcheon v. Federal Election Commission, 134 S. Ct. 1434 (U.S. 2014).

McNally, Dylan. "Mexico's National Electoral Institute: Ensuring Fair Elections at the Local Level," Baker Institute (2014), <http://www.bakerinstitute.org/files/7851/.

Molenaar, Fransje and Rocio Martínez, Mexico Elections 2012: A Study of the Regulation and Oversight of Political Parties' Financial Resources, IFES (2012).

Mutch, Robert E. Buying the Vote: A History of Campaign Finance Reform, Oxford University Press (2014).

National Citizens' Coalition v. Canada (Attorney General), 5 WWR 436 (Alta QB 1984).

Nixon v. Shrink Missouri Government PAC, 528 U.S. 377 (2000).

O’Neil, Shannon K. "Campaign Financing in Mexico," Council on Foreign Relations (blog) (July 10, 2013), <http:// blogs.cfr.org/oneil/2013/07/10/campaign-financing-inmexico/>.

Orozco Henríquez, José De Jesús. "Financing and Monitoring Political Parties in Mexico: Strengths and Weaknesses," Election Law Journal, 3 (2004), p. 463.

Peschard, Jacqueline. "Federal and Local Electoral Institutions: From a National to a Fragmented System," in Andrew Selee and Jacqueline Peschard (eds.), Mexico's Democratic 
Challenges: Politics, Government, and Society, Woodrow Wilson Press (2010).

Persily, Nathaniel. "Stronger Parties as a Solution to Polarization," in Nathaniel Persily (ed.), Solutions to Political Polarization in America, Cambridge University Press (2015).

Peschard, Jacqueline. "Control over Party and Campaign Finance in Mexico," Mexico Studies, 22 (2006), p. 83.

Peschard, Jacqueline. "Mexico's Search for Credibility," Election Law Journal, 3 (2004), p. 412.

Pildes, Richard H. "Romanticizing Democracy, Political Fragmentation, and the Decline of American Government," Yale Law Journal, 124 (2014), p. 804.

Pildes, Richard H. "Why the Center Does Not Hold: The Causes of Hyperpolarized Democracy in America," California Law Review, 99 (2011), p. 273.

Poiré, Alejandro. "Tackling Corruption in Mexico Means Reforming Campaign Finance," Financial Times (Dec. 12, 2014), <https://www.ft.com/content/2161a2f9-a59b-3aefb0bd-46ba92011fe5>.

Potter, Trevor and Bryson B. Morgan, "The History of Undisclosed Spending in U.S. Elections \& How 2012 Became the 'Dark Money' Election," Notre Dame Journal of Law Ethics \& Public Policy, 27 (2013), p. 383.

Prud'homme, Jean-François. "The Restructuring of the Party System in the Wake of the 2006 Elections," in Andrew Selee and Jacqueline Peschard (eds.), Mexico's Democratic Challenges: Politics, Government, and Society, Woodrow Wilson Center Press (2010).

Public Citizen, Roiled in Partisan Deadlock, Federal Election Commission Is Failing (2016), <http://www.citizen.org/ documents/fec-deadlock-update-april-2015.pdf $>$.

Randall v. Sorrell, 548 U.S. 230 (U.S. 2006).

Ravel, Ann M. and Ellen L. Weintraub, "Statement of Vice Chair Ann M. Ravel and Commissioner Ellen L. Weintraub on Judicial Review of Deadlocked Commission Votes" (June 17, 2014), <http://eqs.fec.gov/eqsdocsMUR/14044354045 .pdf $>$.

Reuters Staff, "Incoming Mexico Leader Blasts Campaign Fine as 'Act of Vengeance,"' Reuters (July 20, 2018), <https:// www.reuters.com/article/us-mexico-election-lopezobrador/ incoming-mexico-leader-blasts-campaign-fine-asact-ofvengeance-idUSKBN1KB017>.

Royal Commission on Electoral Reform and Party Financing, Reforming Electoral Democracy, Minister of Supply and Services Canada (1991).

Schattschneider, E.E. Party Government, Holt, Rinehart and Winston (1942).

Serra, Gilles. "The Risk of Partyarchy and Democratic Backsliding: Mexico's 2007 Electoral Reform," Taiwan Journal of Democracy, 8 (2012), p. 31.

Serra, Gilles. "The 2012 Elections in Mexico: Return of the Dominant Party,” Electoral Studies, 34 (2014), p. 349.

Simon, Donald. "Current Regulation and Future Challenges for Campaign Finance in the United States," Election Law Journal, 3 (2004), p. 474.

Smith, Bradley A. and Stephen M. Hoersting, "A Toothless Anaconda: Innovation, Impotence, and Overenforcement at the Federal Election Commission," Election Law Journal, 1 (2002), p. 145.

Stoney, Christopher and Catherine Waters, "The Federal Accountability Act: The Impact of Changes in Party Finances on the Democratic Functions of Political Parties," Journal of Parliamentary \& Political Law, 1 (2008), p. 155.

Theriault, Sean. Party Polarization in Congress, Cambridge University Press (2008).

Thomas, Paul G. and Lorne R. Gibson, Comparative Assessment of Central Electoral Agencies: A Report Commissioned by Elections Canada (2014).

Tokaji, Daniel P. "The Future of Election Reform: From Rules to Institutions," Yale Law \& Policy Review, 28 (2009), p. 125.

Tokaji, Daniel P. and Renata E.B. Strause, The New Soft Money: Outside Spending in Congressional Elections, Election Law @ Moritz, The Ohio State University, Moritz College of Law (2014).

Tokaji, Daniel P. "The Obliteration of Equality in American Campaign Finance Law: A Trans-Border Comparison," Journal of Parliamentary \& Political Law, 5 (2011), p. 381.

Tribunal Electoral del Poder Judicial de la Federacíón or Electoral Tribunal, Statistics, <http://www.trife.gob.mx/en/turnossentencias/statistics $>$.

Ugalde, Luis Carlos and Mario Guzmán, "En las Urnas: Más Dinero, Más Corrupción” Nexos (Aug. 1, 2013), <https:// www.nexos.com.mx/?p=15453>.

Ugues, Jr. Antonio and D. Xavier Medina Vidal, "Public Evaluations of Electoral Institutions in Mexico: An Analysis of the IFE and TRIFE in the 2006 and 2012 Elections," Electoral Studies, 40 (2015), p. 231.

Weintraub, Ellen L. and Samuel C. Brown, "Following the Money: Campaign Finance Disclosure in India and the United States," Election Law Journal 11 (2012), p. 241.

Wertheimer, Fred and Don Simon, The FEC: The Failure to Enforce Commission, ACS Issue Brief (2013), <http://www .democracy21.org/wp-content/uploads/2013/02/Wertheimerand-Simon-The-Failure-to-Enforce-Commission-.pdf $>$.

Young, Lisa. "Regulating Campaign Finance in Canada: Strengths and Weaknesses," Election Law Journal, 3 (2004), p. 444.

Young, Lisa. "Shaping the Battlefield: Partisan Self-Interest and Election Finance Reform in Canada, 2003-2014," in Robert G. Boatright (ed.), The Deregulatory Moment?: A Comparative Perspective on Changing Campaign Finance Laws, University of Michigan Press (2015).

Address correspondence to: Daniel P. Tokaji

The Ohio State University Moritz College of Law 55 West 12th Avenue Columbus, OH 43210

E-mail: tokaji.1@osu.edu 